\title{
Correction to: First record of the Phoenix Islands damselfish Plectroglyphidodon phoenixensis (Schultz, 1943) from the Northwestern Hawaiian Islands
}

\author{
Randall K. Kosaki ${ }^{1^{*}}$ (1) and Julia M. Hart ${ }^{2}$
}

\section{Correction}

Following publication of the original article (Kosaki and Hartl 2018), the authors reported an error in the caption of Fig. 2. The caption contains the reference "Schultz, 1043", which should be "Schultz, 1943". Figure 2 and its corrected caption are given below.

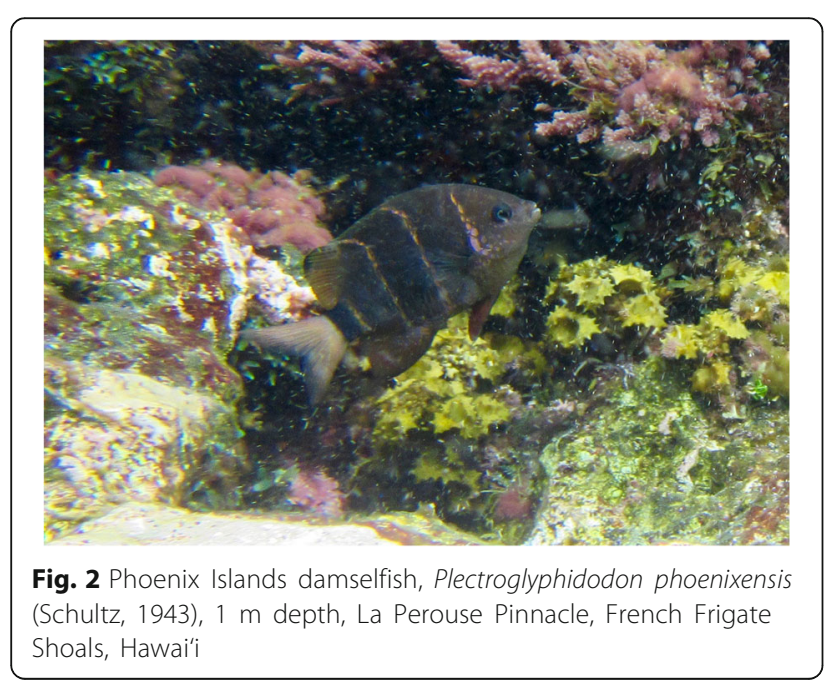

\footnotetext{
* Correspondence: randall.kosaki@noaa.gov

${ }^{1}$ National Oceanic and Atmospheric Administration, Papahānaumokuākea Marine National Monument, 1845 Wasp Boulevard, Building 176, Honolulu, HI 96818, USA

Full list of author information is available at the end of the article
}

\author{
Author details \\ ${ }^{1}$ National Oceanic and Atmospheric Administration, Papahānaumokuākea \\ Marine National Monument, 1845 Wasp Boulevard, Building 176, Honolulu, HI \\ 96818, USA. ${ }^{2}$ One Ocean Diving and Research, 66-105 Haleiwa Beach Rd, \\ Haleiwa, HI 96712, USA. \\ Received: 21 April 2018 Accepted: 1 May 2018 \\ Published online: 11 June 2018 \\ Reference \\ Kosaki RK, Hartl JM. First record of the Phoenix Islands damselfish \\ Plectroglyphidodon phoenixensis (Schultz, 1943) from the Northwestern \\ Hawaiian Islands. Marine Biodiversity Records. 2018;11:7. https://doi.org/10. \\ 1186/s41200-018-0142-5.
}

(c) The Author(s). 2018 Open Access This article is distributed under the terms of the Creative Commons Attribution 4.0 International License (http://creativecommons.org/licenses/by/4.0/), which permits unrestricted use, distribution, and reproduction in any medium, provided you give appropriate credit to the original author(s) and the source, provide a link to the Creative Commons license, and indicate if changes were made. The Creative Commons Public Domain Dedication waiver (http://creativecommons.org/publicdomain/zero/1.0/) applies to the data made available in this article, unless otherwise stated. 